\title{
Brine Shrimp (Artemia salina Leach.) Lethality Test of Ethanolic Extract from Green Betel (Piper bet/e Linn.) and Red Betel (Piper crocatum Ruiz and Pav.) through the Soxhletation Method for Cytotoxicity Test
}

\author{
Nerdy Nerdy ${ }^{1 *}$, Puji Lestari ${ }^{1}$, Jon Piter Sinaga ${ }^{2}$, Selamat Ginting ${ }^{2}$, Nilsya Febrika Zebua ${ }^{3}$, Vriezka Mierza ${ }^{3}$, Tedy Kurniawan Bakri \\ ${ }^{1}$ Department of Pharmacy, Faculty of Pharmacy, Institut Kesehatan Deli Husada Deli Tua, Deli Serdang, Sumatera Utara, Indonesia; \\ ${ }^{2}$ Department of Public Health, Faculty of Public Health, Institut Kesehatan Deli Husada Deli Tua, Deli Serdang, Sumatera Utara, \\ Indonesia; ${ }^{3}$ Department of Pharmacy, Faculty of Pharmacy, Universitas Tjut Nyak Dhien, Medan, Sumatera Utara, Indonesia; \\ ${ }^{4}$ Department of Pharmacy, Faculty of Mathematics and Natural Sciences, Universitas Syiah Kuala, Banda Aceh, Aceh, Indonesia
}

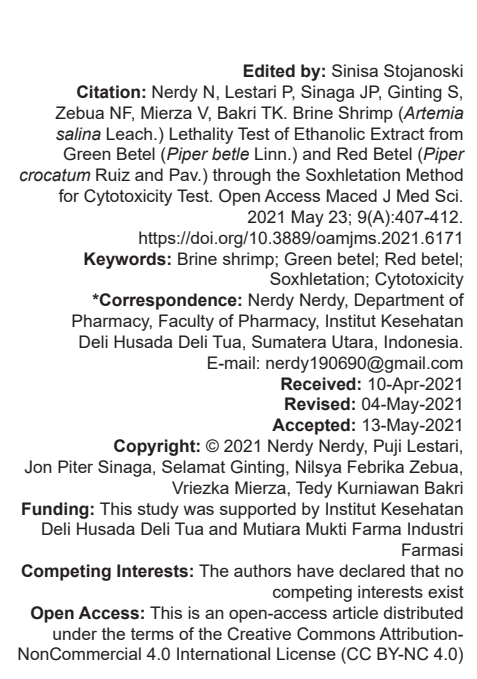

\section{Abstract}

BACKGROUND: Traditional medicine is currently being explored and developed widely by various countries because its cost effectiveness and reduced side effects. The green betel (Piper betle Linn.) and the red betel (Piper crocatum Ruiz and Pav.) are plants from the same Piper genus that are widely cultivated in Indonesia and have various phytochemical properties and pharmacological effects.

AIM: The objective of this research is to determine the cytotoxicity of green leaves and red betel leaves.

METHODS: This research was conducted in two main stages: First, the extraction and preparation through the soxhletation method; and second, a cytotoxicity test through the brine shrimp (Artemia salina Leach) lethality test.

RESULTS: The results showed that there was lethal concentration $50 \%$ (LC ) value in both green betel leaves ethanolic extract and red betel leaves ethanolic extract, with $44.975 \mu \mathrm{g} / \mathrm{mL}$ and $31.556 \mu \mathrm{g} / \mathrm{mL}$, respectively. The red betel leaves ethanolic extract has a higher cytotoxicity than green betel leaves ethanolic extract which can be seen from the lower $\mathrm{LC}_{50}$ value.

CONCLUSIONS: The difference in cytotoxicity is due to differences in plant varieties that cause variations in phytochemical content which affects the pharmacological effects. The green betel leaves ethanolic extract and the red betel leaves ethanolic extract are cytotoxic and have potential anticancer properties.

\section{Introduction}

Traditional medicine is defined as medicine that comes from herbal plants and has been known since ancient times. Traditional medicine has been relied on for generations because it is inexpensive and often has fewer side effects compared to modern day medicine [1], [2]. Additional research on plants used as traditional medicines is still needed through preclinical testing and clinical testing so that they can safely be used in health care facilities [3]. Many herbal plants still have unknown cytotoxicity levels. Traditional medicines that have cytotoxicity have the potential to be developed as anticancer drugs [4].

The number of cancer patients has increased from 2010 to 2020 and is the leading cause of death worldwide. The mortality versus success rates are very much influenced by the type of cancer, the stage of the cancer, the patient's general health level, and the passion of the patient to recover [5]. There are many ways to treat cancer and one of them is through medicinal plants. In fact, the advancement of modern science and technology has not shifted the role of traditional medicine, but rather enhanced and complemented its practices [6].

The betel plant of the Piper genus with the subcategories of the green betel (Piper betle Linn.) and red betel (Piper crocatum Ruiz and Pav.) is widely cultivated in Indonesia. The leaves have phytochemicals that are pharmacologically active and are often used for several treatments. This is because the green betel leaves and the red betel leaves contain antioxidant [7], antidiabetic [8], antifungal [9], and antibacterial [10] properties.

The brine shrimp (Artemia salina Leach) lethality test (BSLT) method is often used to detect the 
presence of compounds that have cytotoxicity in the process of active compounds isolation from natural materials by determination of the lethal concentration $50 \%\left(\mathrm{LC}_{50}\right)$ value [11]. Based on the preliminary studies, the researchers are interested in using the brine shrimp lethality to measure the cytotoxicity of green betel leaves ethanolic extract and red betel leaves ethanolic extract obtained through the soxhletation method.

\section{Methods}

\section{Research description}

This study is an experimental study to test the cytotoxicity of green betel leaves ethanolic extract and red betel leaves ethanolic extract. The extraction process is carried out through the soxhletation method using a Soxhlet extractor, then evaporated with a rotary evaporator, and concentrated with a water bath. A cytotoxic effects test was carried out through the BSLT method at various extract concentrations.

\section{Samples}

This study used samples of green betel leaves and red betel leaves each obtained from Research Plantations in Mutiara Mukti Farma Pharmaceutical Industry. The plant determination and taxonomy were carried out at the Herbarium Medanese by Biology Department, Faculty of Mathematics and Natural Sciences, Universitas Sumatera Utara.

\section{Animal test}

This study involved brine shrimp larvae which were obtained from the Research Laboratory in Mutiara Mukti Farma Pharmaceutical Industry. The animal determination was carried out at the Animal Systematic Laboratory by Biology Department, Faculty of Mathematics and Natural Sciences, Universitas Sumatera Utara.

\section{Ethical clearance}

The research protocol was reviewed by the Biology Department, Faculty of Mathematics and Natural Sciences, University of North Sumatra's Ethics Commission to obtain ethical clearances.

\section{Tools}

This study used the following tools: A cutter (Tekiro), drying cabinet (Alumex), blender (Philips), analytical balance (Sartorius), hotplate stirrer (Thermo), Soxhlet extractor (Iwaki), filter paper (Whatman), rotary evaporator (Buchi), water bath (Memmert), vortex (lka), desiccator (Brand), aerator (Amara), lamp (Hannoch), brine incubator (Vivaria), and loupe (Joyart).

\section{Materials}

This study relied on ethanol (Merck), larvae of $A$. salina Leach (Fishowner), and sodium chloride (Merck).

\section{Extract preparation}

To extract the green and red betel leaves, the soxletation method from Dianursanti et al. (2020) was used with minor modifications [12]. The green betel leaves and red betel leaves were picked in the morning, washed under running water, drained to dry, weighed, dried in a drying cabinet for 3 days until dry, blended in a blender to powder form, and weighed again. The extraction was carried out through the soxhletation method by weighing $50 \mathrm{~g}$ of dried sample, which was then wrapped in filter paper. The sample was inserted into the Soxhlet extractor, combined with $500 \mathrm{~mL}$ of ethanol in a round bottom flask, coupled with a soxlet extractor with a condenser, extracted until the liquid soaking the sample is colorless, evaporated the dilute extract using an evaporator, then evaporated using a water bath until a concentrate extract was obtained.

\section{$B S L T$}

The cytotoxicity test used was the BSLT from Supomo et al. (2019) with minor modification [13]. The brine shrimp larvae were prepared by weighing $5 \mathrm{~g}$ of brine shrimp eggs, inserting them into a brine incubator, soaking the eggs in $250 \mathrm{~mL}$ of artificial sea water (40 g salt in $2 \mathrm{~L}$ of water), lighting them with a 50 watt lamp, and aerating them for $48 \mathrm{~h}$. The cytotoxicity test was carried out by weighting $50 \mathrm{mg}$ of the extract, which was dissolved in $5 \mathrm{ml}$ of ethanol (obtained from a stock solution with an extract concentration of $10000 \mu \mathrm{g} / \mathrm{mL}$ ), pipetted in concentrations of $1000 \mu \mathrm{L}, 500 \mu \mathrm{L}, 250 \mu \mathrm{L}$, $100 \mu \mathrm{L}, 50 \mu \mathrm{L}, 25 \mu \mathrm{L}$, and $10 \mu \mathrm{L}$, inserted into vials, and left for $24 \mathrm{~h}$ to evaporate the solvent. Next $5 \mathrm{~mL}$ of artificial sea water was added and homogenized with a vortex (obtained test solution with extract concentration $1000 \mu \mathrm{g} / \mathrm{mL}, 500 \mu \mathrm{g} / \mathrm{mL}, 250 \mu \mathrm{g} / \mathrm{mL}, 100 \mu \mathrm{g} / \mathrm{mL}$, $50 \mu \mathrm{g} / \mathrm{mL}, 25 \mu \mathrm{g} / \mathrm{mL}$, and $10 \mu \mathrm{g} / \mathrm{mL}$ ). Ten brine shrimp larvae were added to each vial, along with $50 \mu \mathrm{L}$ of yeast suspension as food. The vials were placed under the heat lamp and left for $24 \mathrm{~h}$ with observation at $0 \mathrm{~h}, 1 \mathrm{~h}$, $2 \mathrm{~h}, 3 \mathrm{~h}, 4 \mathrm{~h}, 5 \mathrm{~h}, 6 \mathrm{~h}, 12 \mathrm{~h}, 18 \mathrm{~h}$, and $24 \mathrm{~h}$. At each interval the dead larvae were counted using a loupe (larvae that did not show movement for $10 \mathrm{~s}$ were declared dead) and the death percentage was calculated. This was repeated 3 times for each extract concentration, and determined the $\mathrm{LC}_{50}$ value with probit analysis using the Statistical Package for the Social Sciences (SPSS) 
application with $26^{\text {th }}$ Version. An extract is declared active if it has a $L_{50}$ value $<1000 \mu \mathrm{g} / \mathrm{mL}$. There was a total of 420 brine shrimp larvae used throughout the experiment. The larvae used are $48 \mathrm{~h}$ old, because at this age, the larvae have complete limbs.

\section{Results and Discussion}

The green betel leaves' ethanolic extract appeared to have a viscous texture, specific aroma, and brownish-green color. The red betel leaves ethanolic extract appeared to have a viscous texture, specific aroma, and brownish red color. The yield percentage of green betel leaves ethanolic extract and red betel leaves ethanolic extract each was calculated based on fresh sample and dry samples. Table 1 showed the yield percentage of green leaves ethanolic extract and red betel leaves ethanolic extract based on fresh and dry samples.

Table 1: The yield percentage of green betel ( $P$. betle Linn.) leaves ethanolic extract and red betel ( $P$. crocatum Ruiz and Pav.) leaves ethanolic extract based on fresh and dry samples

\begin{tabular}{|c|c|c|c|c|c|}
\hline \multirow[t]{2}{*}{ Sample } & \multicolumn{3}{|c|}{ Weight } & \multicolumn{2}{|c|}{ Yield percentage of extract } \\
\hline & Fresh & Dry & Extract & $\begin{array}{l}\text { Based on } \\
\text { Fresh Sample }\end{array}$ & $\begin{array}{l}\text { Based on } \\
\text { Dry Sample }\end{array}$ \\
\hline $\begin{array}{l}\text { Green betel leaves } \\
(P . \text { betle Linn.) }\end{array}$ & $1 \mathrm{~kg}$ & $497 \mathrm{~g}$ & $4.72 \mathrm{~g}$ & 4.69 & 9.44 \\
\hline $\begin{array}{l}\text { Red betel leaves } \\
\text { (P. crocatum Ruiz and Pav.) }\end{array}$ & $1 \mathrm{~kg}$ & $519 \mathrm{~g}$ & $5.12 \mathrm{~g}$ & 5.31 & 10.24 \\
\hline
\end{tabular}

The yield percentage of red betel leaves ethanolic extract was higher than the yield percentage of green betel leaves ethanolic extract. Macroscopic examination results show that green betel leaf is a single leaf, brownish green leaf color. Macroscopic examination results show that red betel leaf is a single leaf, reddish green leaf color. Both green betel leaves and red betel leaves have oval to oval blades; a pointed tip; heart-shaped, rounded, or curved base; and have a distinctive smell. The results of microscopic examination of green betel leaves and red betel leaves have found fragments in the form of anomocytic-type stomata, essential oil in the parenchyma cells, trichomes, and oil cells in the hypodermis and xylem [14].

The test results show that various concentrations of extract could kill brine shrimp larvae in series concentrations, including, $1000 \mu \mathrm{g} / \mathrm{mL}$, $500 \mu \mathrm{g} / \mathrm{mL}, 250 \mu \mathrm{g} / \mathrm{mL}, 100 \mu \mathrm{g} / \mathrm{mL}, 50 \mu \mathrm{g} / \mathrm{mL}, 25 \mu \mathrm{g} / \mathrm{mL}$, $10 \mu \mathrm{g} / \mathrm{mL}$, and $0 \mu \mathrm{g} / \mathrm{mL}$. Table 2 displays the data for the brine shrimp larvae death rate at various observation intervals and concentration levels of green betel leaves ethanolic extract. Table 3 displays the data for the brine shrimp larvae death rate at various observation intervals and concentration levels of red betel leaves ethanolic extract. Figure 1 charts the brine shrimp larvae deaths at various observation intervals in various concentrations of green betel leaves ethanolic extract. Figure 2 charts the brine shrimp larvae deaths at various observation
Table 2: The deaths of brine shrimp (A. salina Leach.) larvae data at various observation intervals in various concentrations of green betel ( $P$. betle Linn.) leaves ethanolic extract

\begin{tabular}{|c|c|c|c|c|c|c|c|c|c|c|c|}
\hline \multirow[t]{2}{*}{ Sample } & \multirow[t]{2}{*}{ Concentration } & \multicolumn{10}{|c|}{ Average deaths of brine shrimp (A. salina Leach.) Larvae } \\
\hline & & $0 \mathrm{~h}$ & $1 \mathrm{~h}$ & $2 \mathrm{~h}$ & $3 \mathrm{~h}$ & $4 \mathrm{~h}$ & $5 \mathrm{~h}$ & $6 \mathrm{~h}$ & $12 \mathrm{~h}$ & $18 \mathrm{~h}$ & $24 \mathrm{~h}$ \\
\hline \multirow{7}{*}{$\begin{array}{l}\text { Green betel } \\
\text { leaves } \\
\text { (P. betle Linn.) } \\
\text { ethanolic } \\
\text { extract }\end{array}$} & 10 & 0.00 & 0.00 & 0.00 & 0.00 & 0.00 & 0.33 & 1.00 & 1.67 & 2.00 & 3.00 \\
\hline & 25 & 0.00 & 0.00 & 0.00 & 0.00 & 0.67 & 1.33 & 1.67 & 2.67 & 3.67 & 4.33 \\
\hline & 50 & 0.00 & 0.00 & 0.00 & 0.67 & 1.00 & 1.67 & 2.00 & 3.00 & 4.00 & 5.00 \\
\hline & 100 & 0.00 & 0.67 & 1.00 & 1.33 & 2.00 & 2.33 & 3.00 & 4.00 & 5.00 & 6.00 \\
\hline & 250 & 0.00 & 1.33 & 2.33 & 2.67 & 3.33 & 3.67 & 4.33 & 5.33 & 6.33 & 7.33 \\
\hline & 500 & 0.00 & 1.67 & 2.33 & 3.00 & 3.67 & 4.67 & 5.33 & 6.33 & 7.33 & 8.33 \\
\hline & 1000 & 0.00 & 2.33 & 3.00 & 3.67 & 4.67 & 5.33 & 6.00 & 7.00 & 8.00 & 9.00 \\
\hline
\end{tabular}

intervals in various concentrations of red betel leaves ethanolic extract.

Table 3: The deaths of brine shrimp ( $A$. salina Leach.) larvae data at various observation intervals in various concentrations of red betel ( $P$. crocatum Ruiz and Pav.) leaves ethanolic extract

\begin{tabular}{|c|c|c|c|c|c|c|c|c|c|c|c|}
\hline \multirow[t]{2}{*}{ Sample } & \multirow[t]{2}{*}{ Concentration } & \multicolumn{10}{|c|}{ Average deaths of brine shrimp (A. salina Leach.) Larvae } \\
\hline & & $0 \mathrm{~h}$ & $1 \mathrm{~h}$ & $2 \mathrm{~h}$ & $3 \mathrm{~h}$ & $4 \mathrm{~h}$ & $5 \mathrm{~h}$ & $6 \mathrm{~h}$ & $12 \mathrm{~h}$ & $18 \mathrm{~h}$ & $24 \mathrm{~h}$ \\
\hline Red betel & 10 & 0.00 & 0.00 & 0.00 & 0.00 & 0.00 & 1.33 & 1.67 & 2.00 & 2.67 & 3.33 \\
\hline leaves & 25 & 0.00 & 0.00 & 0.00 & 0.33 & 1.33 & 2.00 & 2.67 & 3.33 & 4.00 & 4.67 \\
\hline (P. crocatum & 50 & 0.00 & 0.00 & 0.67 & 1.00 & 1.67 & 2.00 & 2.67 & 3.67 & 4.67 & 5.67 \\
\hline Ruiz and & 100 & 0.33 & 0.67 & 1.33 & 1.67 & 2.33 & 3.00 & 3.67 & 4.67 & 5.67 & 6.67 \\
\hline Pav.) & 250 & 0.00 & 1.67 & 2.67 & 3.33 & 3.67 & 4.33 & 5.00 & 6.00 & 7.00 & 8.00 \\
\hline ethanolic & 500 & 0.00 & 2.33 & 3.00 & 3.33 & 4.33 & 5.33 & 6.00 & 7.00 & 8.00 & 9.00 \\
\hline extract & 1000 & 0.00 & 3.67 & 4.33 & 5.33 & 5.67 & 6.33 & 7.00 & 8.00 & 9.00 & 10.00 \\
\hline
\end{tabular}

The total mortality rate was obtained by counting the larvae that died at each concentration. The response to death at a concentration of $1000 \mu \mathrm{g} / \mathrm{mL}$ was the fastest mortality rate and the greatest mortality value. The results of the total deaths after $24 \mathrm{~h}$ were analyzed with probit analysis using the $26^{\text {th }}$ version of the SPSS application to obtain a $\mathrm{LC}_{50}$ value. The analysis results showed that correlation coefficient of the logarithm of the concentration to the percentage of mortality from brine shrimp larvae was 0.998 for green betel leaves ethanolic extract and 0.999 for red betel leaves ethanolic extract. This correlation coefficient meets the requirements of $>0.99$ to indicate the almost perfect correlation and almost perfect relationship between axis and ordinate [15]. Therefore, increasing the green betel leaves ethanolic extract concentration and the red betel leaves ethanolic extract concentration further increases the mortality rate and the mortality number of brine shrimp larvae. The medicinal plants extract generally provides cytotoxicity to brine shrimp larvae with a concentration dependent activity profile [16]

The $\mathrm{LC}_{50}$ value of green betel leaves ethanolic extract and red betel leaves ethanolic extract was, respectively, $44.975 \mu \mathrm{g} / \mathrm{mL}$ and $31.556 \mu \mathrm{g} / \mathrm{mL}$. The extract showed cytotoxicity in a BSLT if the extract could cause the death of $50 \%$ of the tested animals at a concentration $<1000 \mu \mathrm{g} / \mathrm{mL}$ [17], [18]. Based on this previous research green betel leaves ethanolic extract and red betel leaves ethanolic extract have a cytotoxic effect and may have promising potential for further development in anticancer drugs [19].

Variation in the concentration of green betel leaves ethanolic extract and red betel leaves ethanolic extract in this experiment results in different mortality rates for the brine shrimp larvae. This indicates that cytotoxicity 


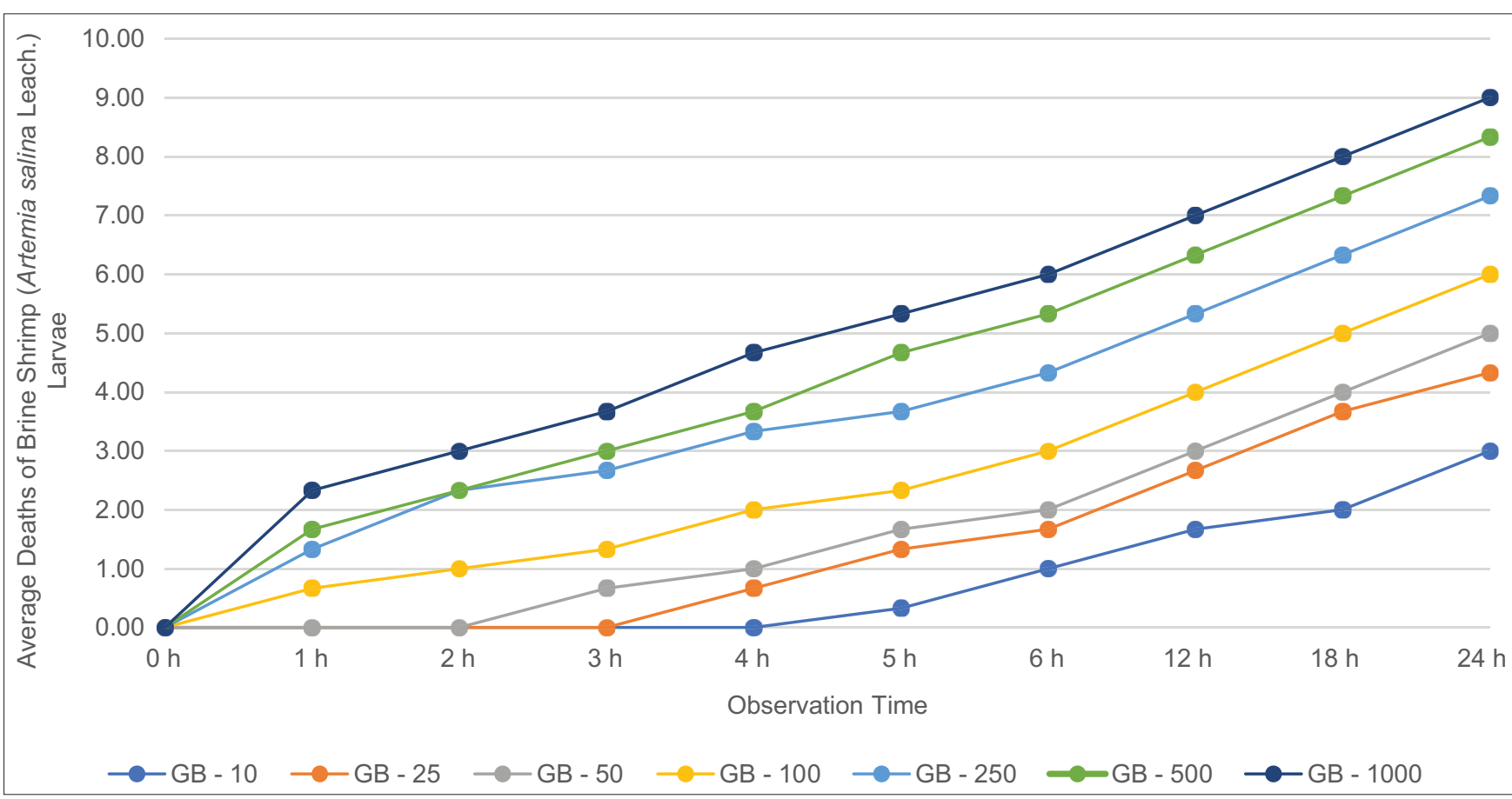

Figure 1: The chart of deaths of brine shrimp (Artemia salina Leach.) larvae at various observation intervals in various concentrations of green betel (Piper betle Linn.) leaves ethanolic extract. GB: Green betel (Piper betle Linn.) leaves ethanolic extract

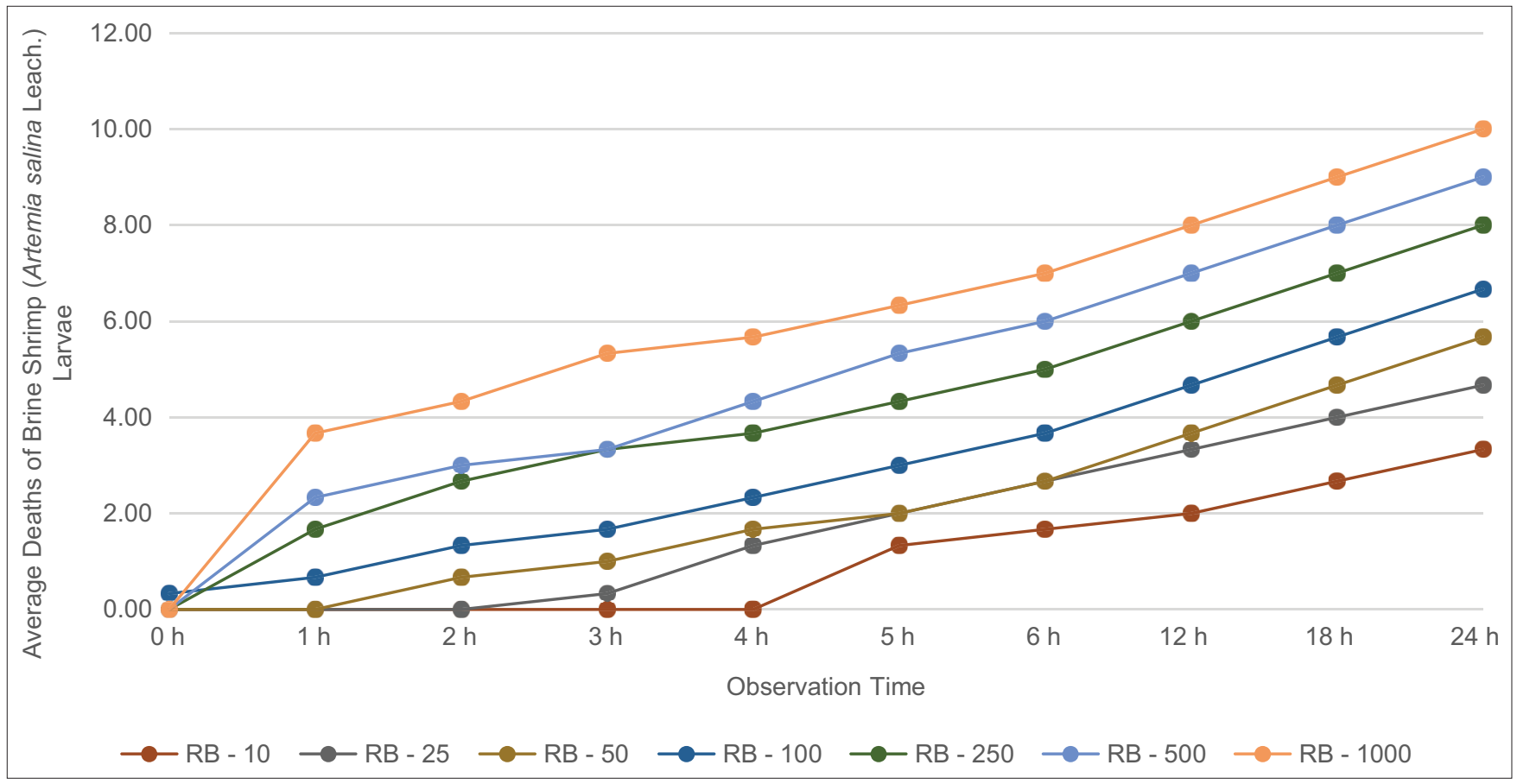

Figure 2: The chart of deaths of brine shrimp (Artemia salina Leach.) larvae at various observation intervals in various concentrations of red betel (Piper crocatum Ruiz and Pav.) leaves ethanolic extract. RB: Red betel (Piper crocatum Ruiz and Pav.) leaves ethanolic extract

of the green leaves ethanolic extract and red betel leaves ethanolic extract were concentration dependent. This result is in accordance with several previous studies that show cytotoxicity is concentration dependent in traditionally medicinal plants' extracts [20], [21], [22].

The cytotoxicity test using the BSLT method is very important as a preliminary test for anticancer properties. If the test results show cytotoxicity, the cytotoxicity test can be continued on human cancer cells [23]. The brine shrimp ( $A$. salina Leach.) larvae used are $48 \mathrm{~h}$ old, because at this age the larvae have complete limbs, were in the I-III instar phase, and were the most sensitive to the test material [24].

Plant compounds are an important source of therapeutic compounds for cancer treatment. Phytochemical content contained in green betel leaves 
ethanolic extract and red betel leaves ethanolic extract has potentially anticancer properties. The phytochemical content contained in green betel leaves ethanolic extract and red betel leaves ethanolic extract is alkaloids, flavonoids, steroids, monoterpenes, triterpenes, sesquiterpenes, tannins, and glycosides [25], [26].

The death mechanism of brine shrimp larvae is related to the function of alkaloid compounds in green betel leaves ethanolic extract and red betel leaves ethanolic extract which can diffuse through the cell membrane of brine shrimp larvae, causing damage or modification of the membrane's permeability and disrupting the substance transfer system which can interfere with biochemical processes and physiological processes [27]. The entry of toxic substances into the brine shrimp larvaes' digestive tracts as non-selective filter so that anything that can enter the mouth of brine shrimp seems to be food. The compounds that enter can interact with the target (e.g. enzymes, fats, cell membranes, and nucleic acids) so the compounds affect the body's mechanisms which eventually lead to death [28], [29].

Flavonoids in green betel leaves ethanolic extract and red betel leaves ethanolic extract contribute to brine shrimp larvae death through the mechanism of causing stomach poisoning which will irritate the brine shrimp larvae's digestive systems. Flavonoids also work by inhibiting the taste receptors of the brine shrimp larvae which cause the larvae to fail in the food intake so the brine shrimp larvae experience hunger and die [30]. Flavonoid compounds play a role in providing cytotoxic effects on brine shrimp larvae both in extract and pure isolate form [31]. Higher alkaloid levels and higher flavonoid levels result in an extract becoming more cytotoxic and result in a decrease $L C_{50}$ values so that there is higher anticancer potential [32].

Terpenoids have been proposed as a relevant class found in several plant species, which have pharmacological properties [33]. Terpenoids are believed to facilitate medicinal effects, as several studies have shown that terpenoids compounds show chemopreventive and chemotherapeutic properties against cancer in humans [34]. Terpenoids, the monoterpene class, triterpene class, and sesquiterpene class are useful as a beneficial agent for use as an anticancer drug for the treatment of tumors that are resistant to chemotherapy and for minimizing the side effects of current treatments [35], [36], [37].

From the results, it can be seen that red betel leaves ethanolic extract has a lower $\mathrm{LC}_{50}$ value than green betel leaves ethanolic extract. These results indicate that red betel leaves ethanolic extract has a higher cytotoxicity than green betel leaves ethanolic extract. The lower $\mathrm{LC}_{50}$ value indicates a higher cytotoxic effect [38]. This difference in cytotoxicity because of differences in plant species and variety that cause qualitatively differences and quantitatively differences in the phytochemical content of primary and secondary metabolites contained in the extract [39].

\section{Conclusions}

The cytotoxicity test using the BSLT method of green betel ( $P$. betle Linn.) leaves ethanolic extract and red betel ( $P$. crocatum Ruiz and Pav.) leaves ethanolic extract obtained by the soxhletation method have $\mathrm{LC}_{50}$ value, respectively, $44.975 \mu \mathrm{g} / \mathrm{mL}$ and $31.556 \mu \mathrm{g} /$ $\mathrm{mL}$. These results show that green betel leaves ethanolic extract and red betel leaves ethanolic extract are cytotoxic and have the potential anticancer properties.

\section{Acknowledgment}

The authors would like to thank the Institut Kesehatan Deli Husada Deli Tua for granting this research fund and Mutiara Mukti Farma Industri Farmasi for supplying the samples, animals, materials, and tools.

\section{References}

1. Yuan $H, M a Q, Y e L, P i a o G$. The traditional medicine and modern medicine from natural products. Molecules. 2016;21(5):559. https://doi.org/10.3390/molecules21050559 PMid:27136524

2. Subramaniyan $V$, Kayarohanam $S$, Janakiraman AK, Kumarasamy V. Impact of herbal drugs and its clinical application. Int J Res Pharm Sci. 2019;10(2):1340-5. https://doi. org/10.26452/ijrps.v10i2.537

3. Parveen A, Parveen B, Parveen R, Ahmad S. Challenges and guidelines for clinical trial of herbal drugs. J Pharm Bioallied Sci. 2015;7(4):329-33. https://doi.org/10.4103/0975-7406.168035 PMid:26681895

4. Khan T, Ali M, Khan A, Nisar P, Jan SA, Afridi S, et al. Anticancer plants: A review of the active phytochemicals, applications in animal models, and regulatory aspects. Biomolecules. 2020;10(1):47. https://doi.org/10.3390/biom10010047 PMid:31892257

5. Sung H, Ferlay J, Siegel RL, Laversanne M, Soerjomataram I, Jemal A, et al. Global cancer statistics 2020: GLOBOCAN estimates of incidence and mortality worldwide for 36 cancers in 185 countries. Ca Cancer J Clin. 2021;71(3):209-49. https://doi. org/10.3322/caac. 21660 PMid:33538338

6. Salmerón-Manzano E, Garrido-Cardenas JA, ManzanoAgugliaro F. Worldwide research trends on medicinal plants. Int J Environ Res Public Health. 2020;17(10):3376. https://doi. org/10.3390/ijerph17103376

PMid:32408690

7. Aara A, Chappidi V, Ramadas MN. Antioxidant activity of eugenol in Piper betel leaf extract. J Family Med Prim Care. 2020;9(1):327-31. https://doi.org/10.4103/jfmpc.jfmpc_809_19 PMid:32110613

8. Arambewela LS, Arawwawala LD, Ratnasooriya WD. 
Antidiabetic activities of aqueous and ethanolic extracts of Piper betle leaves in rats. J Ethnopharmacol. 2020;102(2):239-45. https://doi.org/10.1016/j.jep.2005.06.016

PMid:16055288

9. Sivareddy B, Reginald BA, Sireesha D, Samatha M, Reddy KH Subrahamanyam G. Antifungal activity of solvent extracts of Piper betle and Ocimum sanctum Linn on Candida albicans: An in vitro comparative study. J Oral Maxillofac Pathol. 2019;23(3):333-7 https://doi.org/10.4103/jomfp.jomfp_167_19 PMid:31942110

10. Karsono K, Patilaya P, Azisah N, Nerdy N. Comparison of antimicrobial activity of red betel (Piper crocatum Ruiz and Pav) leaves nanoparticle and powder ethanolic extract against methicillin resistant Staphylococcus aureus. Int J PharmTech Res. 2015;8(4):696-701.

11. Rosyadi A, Faizah RN, Nuri N, Puspitasari E. Anticancer properties of methanolic extract of Piper crocatum leaf using BST and cytotoxicity on HeLa cell lines. Ann Trop Public Health. 2020;23(3A):3-11. https://doi.org/10.36295/asro.2020.2331

12. Dianursanti D, Nugroho P, Prakasa MB. Comparison of maceration and soxhletation method for flavonoid production from Spirulina platensis as a sunscreen's raw material. AIP Conf Proc. 2020;2230:020006. https://doi.org/10.1063/5.0002806

13. Supomo S, Syamsul ES, Apriliana A, Saleh C, Erwin E, Lestari D. Antioxidant assay of dayak onion (Eleutherine palmifolia) via DPPH (1,1-diphenil-2-picrylhydrazyl) and BSLT test for its active fraction. Rasayan J Chem. 2019;12(3):1340-6. https://doi.org/10.31788/rjc.2019.1235264

14. Gupta D, Singh A. Piper betle and some Indian plant for antidepressant activity-a review. Res J Pharm Biol Chem Sci. 2016;7(2):1670-8.

15. Akoglu H. User's guide to correlation coefficients. Turk J Emerg Med. 2018;18(3):91-3.

PMid:30191186

16. Pertiwi D, Hafiz I, Leny L. Potential bioactivities of ethanol, ethyl acetate and $\mathrm{N}$-hexane extracts from pagoda leaves (Clerodendrum paniculatum L.). Rasayan J Chem. 2020;13(4):2313-6. https://doi.org/10.31788/rjc.2020.1345791

17. Simorangkir $M$, Nainggolan $B$, Juwitaningsih $T$, Silaban $S$. The toxicity of $\mathrm{N}$-hexane, ethyl acetate and ethanol extracts of sarang banua (Clerodendrum fragrans Vent Willd) leaves by brine shrimp lethality test (BSLT) method. JPhys Conf Ser. 2021;1811:012053. https://doi.org/10.1088/1742-6596/1811/1/012053

18. Saragih G, Tamrin T, Marpongahtun M, Nasution DY, Abdillah A. Phytochemical screening and toxicity of ethanolic extract of mangrove (Rhizophora mucronata) leaves from Langsa, Aceh Timur. Rasayan J Chem. 2020;13(1):476-80. https://doi. org/10.31788/rjc.2020.1315524

19. Rasidah R, Aulianshah V. Black cumin potential anticancer effect of black cumin seed (Nigella sativa L.) extracts as determined by cytotoxicity test against larvae of Artemia salina leach using brine shrimp lethality test (BSLT). Int J PharmTech Res. 2020;13(2):25-9. https://doi.org/10.20902/ijptr.2019.130204

20. Kosasih K, Sumaryono W, Supriono A, Mudhakir D. Cytotoxicity of ethyl acetate extract of cantigi (Vaccinium varingiaefolium (Blume) Miq.) young leaves on Artemia salina L. larvae, MCF-7, T47D, and VERO cell lines. J Pharmacogn Phytochem. 2019;8(4):24-33.

21. Elsyana V, Bintang M, Priosoeryanto BP. Cytotoxicity and antiproliferative activity assay of clove mistletoe (Dendrophthoe pentandra (L.) Miq.) leaves extracts. Adv Pharmacol Pharm Sci. 2016;2016:3242698. https://doi.org/10.1155/2016/3242698 PMid:27099614

22. Talukder ME, Momen F, Barua R, Sultana S, Yesmin F, Islam MS et al. In vitro assessment of cytotoxic activity of hybrid variety of Momordica charantia (Bitter Gourd). J Phytopharmacol. 2020;9(6):445-8.
23. Hamrun $N$, Nabilah $T$, Hasyim R, Ruslin M, Dammar I, Arianto MA. Toxicity test of bioactive red alga extract Eucheuma spinosum on shrimp Artemia salina leach. Sys Rev Pharm. 2020;11(5):672-6.

24. Ekonomou G, Lolas A, Castritsi-Catharios J, Neofitou C, Zouganelis GD, Tsiropoulos N, et al. Mortality and effect on growth of Artemia franciscana exposed to two common organic pollutants. water. 2019;11(8):1614. https://doi.org/10.3390/w11081614

25. Begam KM, Ravichandran P, Manimekalai V. Phytochemica analysis of some selected varieties of Piper betle L. Int J Curr Pharm Res. 2018;10(2):89-93. https://doi.org/10.22159/ ijcpr.2018v10i2.25884

26. Suri MA, Azizah Z, Asra R. A review-traditional use, phytochemical and pharmacological review of red betel leaves (Piper crocatum Ruiz and Pav). Asian J Pharm Res Dev. 2021;9(1):159-63.

27. Sharififar F, Assadipour A, Moshafi MH, Alishahi F, Mahmoudvand $\mathrm{H}$. Bioassay screening of the essential oil and various extracts of Nigella sativa L. Seeds using brine shrimp toxicity assay. Herbal Med J. 2017;2(1):26-31.

28. Arif MZ, Zainuddin NA, Zakaria IS, Wahab WN, Sul'ain MD. Phytochemical screening and toxicological evaluation of Pyrrosia piloselloides extracts. Int Med J. 2018;25(3):177-80.

29. Jamil S, Khan RA, Afroz S, Ahmed S. Phytochemistry, brine shrimp lethality and mice acute oral toxicity studies on seed extracts of Vernonia anthelmintica. Pak J Pharm Sci. 2016;29(6):2053-7. PMid:28375123

30. Nur S, Mubarak F, Jannah C, Winarni DA, Rahman DA, Hamdayani LA, et al. Total phenolic and flavonoid compounds, antioxidant and toxicity profile of extract and fraction of Paku atai tuber (Angiopteris ferox Copel). Food Res. 2019;3(6):73440. https://doi.org/10.26656/fr.2017.3(6).135

31. Delnavazi MR, Saiyarsarai $P$, Jafari-Nodooshan $S$, Khanavi M, Tavakoli S, Hadavinia $\mathrm{H}$, et al. Cytotoxic flavonoids from the aerial parts of Stachys lavandulifolia Vahl. Pharm Sci. 2018;24:332-9. https://doi.org/10.15171/ps.2018.47

32. Dewijanti ID, Mangunwardoyo W, Artanti N, Hanafi M. Bioactivities of Salam leaf (Syzygium polyanthum (Wight) Walp). AIP Conf Proc. 2019;2168:020072. https://doi.org/10.1063/1.5132499

33. Boncan DA, Tsang SS, Li C, Lee IH, Lam HM, Chan TF, et al. Terpenes and terpenoids in plants: Interactions with environment and insects. Int J Mol Sci. 2020;21(19):7382. https://doi.org/10.3390/ijms21197382 PMid:33036280

34. Proshkina E, Plyusnin S, Babak T, Lashmanova E, Maganova F, Koval L, etal. Terpenoids as potential geroprotectors. Antioxidants. 2020;9(6):529. https://doi.org/10.3390/antiox9060529 PMid:32560451

35. Prakash V. Terpenoids as cytotoxic compounds: A perspective. Pharmacogn Rev. 2018;12(24):166-76.

36. Yang W, Chen X, Li Y, Guo S, Wang Z, Yu X. Advances in pharmacological activities of terpenoids. Nat Prod Commun. 2020;15(3):1-13.

37. Nogueira TS, Passos MS, Nascimento LP, Arantes MB, Monteiro NO, Boeno SI, et al. Chemical compounds and biologic activities: A review of Cedrela genus. Molecules. 2020;25(2):5401. https://doi.org/10.3390/molecules25225401 PMid:33218181

38. Waghulde S, Kale MK, Patil VR. Brine shrimp lethality assay of the aqueous and ethanolic extracts of the selected species of medicinal plants. Proceedings. 2019;41(1):47. https://doi. org/10.3390/ecsoc-23-06703

39. Ni YW, Lin $\mathrm{KH}$, Chen $\mathrm{KH}$, Wu CW, Chang YS. Flavonoid compounds and photosynthesis in Passiflora plant leaves under varying light intensities. Plants. 2020;9(5):633. https://doi. org/10.3390/plants9050633

PMid:32429275 